\title{
Serological Evidence of Pneumonia Virus of Mouse (PVM) Infection in Laboratory Rats
}

\author{
Hironori MIYATA, Yoji WATANABE, Hisayosi KONDO*, \\ Ken-ichi YAGAMI**, and Hiroshi SATO \\ Laboratory Animal Center for Biomedical Research and *Scientific Data Center for Atomic \\ Bomb's Casualty, Nagasaki University School of Medicine, 1-12-4 Sakamoto, \\ Nagasaki-shi, Nagasaki 852, and ${ }^{* *}$ Laboratory Animal Research \\ Center, University of Tsukuba, 1-1-1 Tennodai, \\ Tsukuba-shi, Ibaraki 305, Japan
}

(Received 4 November 1992 / Accepted 23 February 1993)

\begin{abstract}
PVM specific antibody was determined using 3 serological tests (Parker's original hemagglutination-inhibition [HI] test, modified $\mathrm{HI}$ test, and indirect fluorescent antibody [IFA] test). IFA test was found to be the most sensitive method, so that IFA test was considered to be the method of choice for a small scale microbiological monitoring in animal facilities. A total of 1,280 sera including rats, mice, hamsters and rabbits were tested for PVM antibody. The prevalence of PVM antibody was $17.2 \%(116 / 674)$ in conventional rats and $30.0 \%(160 / 200)$ in SPF rats obtained from commercial breeders and research facilities. Furthermore, two samples of 144 conventional rabbits (1.4\%) were showed specific antibody positive to the virus. However, hamsters and mice showed no evidence of PVM infection. These results suggest that PVM infection is prevalent, especially in laboratory rats in Japan.-KEY WORDS : HI, IFA, PVM, rat, seroepidemiology
\end{abstract}

According to recent studies, pneumonia virus of mouse (PVM) which belongs to the pneumovirus group of paramyxoviridae has become one of major respiratory viral diseases prevalent in laboratory animals in North America and Europe $[7,13]$. There are also some reports that PVM frequently caused pulmonary consolidation and severe pneumonia in both immunodeficient and immunocompetent mice which were infected experimentally $[19,21]$. Concerning Japanese laboratory rodents, two studies, in 1978 and $1986[8,9]$, demonstrated the presence of the antibody suggestive of the viral infection in a hemagglutination-inhibition (HI) test using a commercial hemagglutinin (HA) antigen. In these cases, serum samples were not treated with a receptor destroying enzyme (RDE). Moreover, the significance of the low antibody titer detected in HI test was not clear [9]. As the presence of a nonspecific HA inhibitor in normal animal sera was well known in cases of infection with other myxoviruses [2], paramyxoviruses $[5,6]$ and togaviruses $[3,11,18]$, RDE treatment has become to be a common procedure to remove $\mathrm{HA}$ inhibitor (s) from human and animal sera in $\mathrm{HI}$ tests of these viruses. Parker's original HI method for PVM, however, has not adapted this treatment [16]. Regarding this point, the application of RDE treatment in the PVM-HI test was first examined in this study. In this paper, the presence of PVM antibody in the sera, especially of rats, from commercial breeders and research facilities was demonstrated by $\mathrm{HI}$ test, and indirect fluorescent antibody (IFA) test.

\section{Materials and Methods}

Animals and sera: Animals from which sera were collected were ddY, ICR, BALB/C, C57BL/6, SJL, and C3H mice; SD, Donryu, Wistar, F344, SHR, WKY, WF, and WKA rats; Syrian hamsters; and Japanese white rabbits. The sera were collected from 4 research facilities and 6 commercial breeding colonies in western and eastern Japan during the period of 1984 to 1990 . Animals were of both sexes and 
were older than 4 weeks of age. They were placed under general anesthesia with diethy 1-ether or pentobarbital and bled at the time of sacrifice for serological examinations. These procedures were conducted under the guideline of Animal Care and Use Committee of Nagasaki University.

Viruses and cell culture: Strain No.15 of PVM, obtained from the American Type Culture Collection, was passaged twice in our laboratory using BHK-21 cells. The medium used was Eagle's minimal essential medium (MEM) supplemented with $10 \%$ heat-inactivated fetal calf serum (FCS). The concentration of FCS was reduced to $2 \%$ for cell maintenance. For the production of HA, BHK-21 cells were inoculated with the virus at a multiplicity of infection (MOI) of about 1 . The infected cells were then incubated for 10 days in $5 \% \mathrm{CO}_{2}$ and $95 \%$ air at $37^{\circ} \mathrm{C}$ with occasional medium change. The cells were subjected to freezing and thawing 3 times and centrifugation at $2,000 \mathrm{rpm}$ for $15 \mathrm{~min}$ at $4^{\circ} \mathrm{C}$. The supernatant was used as $\mathrm{HA}$ for the test, adjusting the titer at 64 to 128 units.

The $Z$ strain of hemagglutinating virus of Japan (HVJ) was provided by $\mathrm{Dr}$. H. Iwai, Rakuno Gakuen University, and passaged twice in embryonated eggs. Chicken embryos at 9 day-old were inoculated with the virus and incubated at $37^{\circ} \mathrm{C}$. The chorioallantoic fluid was recovered, and purified by the same method as PVM, and used for Western blotting.

Antisera against PVM:Two 4 week-old male rats confirmed to be free from PVM infection were infected intranasally with PVM (64 HA units). After 3 weeks, rats were bled under anesthesia with diethyl ether and the sera were collected.

HI test: Sera were treated with receptor -destroying enzyme (RDE) for demolishing the non-specific inhibitor(s) to PVM-HA, and with absorbed with $50 \%$ mouse red blood cells (RBC) to remove the natural HA. Treatment with RDE (Lot No. H-053, Takada Pharm. Co., Osaka) was carried out as follows. One volume of sera was mixed with 3 volumes of $\mathrm{RDE}$ and incubated for overnight at $37^{\circ} \mathrm{C}$. Thereafter, the sera were treated for $20 \mathrm{~min}$ at $60^{\circ} \mathrm{C}$ to inactivate the residual activity of the enzyme. Thus treated sera were diluted two -fold from 1:16 with Dulbecco's phosphate buf- fered saline (PBS) containing $0.01 \%$ gelatin and $0.1 \%$ bovine serum albumin using 96 -well micro U-plates (Sumitomo Co., Osaka), added 4 units of $\mathrm{HA}$ in $25 \mu \mathrm{l}$, incubated at $37^{\circ} \mathrm{C}$ for $1.5 \mathrm{hrs}$, and then added $50 \mu \mathrm{l}$ of $0.5 \%$ mouse RBC. After mixing throughly, the microplates were allowed to stand at room temperature for $1 \mathrm{hr}$. Antibody titers were expressed as the reciprocal of the highest dilution of sera showing complete HA inhibition.

IFA test: The IFA test was performed by a method described previously for lymphocytic choriomeningitis virus [20]. PVM-infected BHK-21 cells were trypsinized at 3-4 days after infection and were resuspended in PBS after being washed once with the growth medium. Cell droplets in $10 \mu \ell$ volume containing 1-2 x $10^{5} \mathrm{cells} / \mathrm{m} \ell$ were mounted onto ring-spot slides (Matsunami Glass Co., Tokyo) and air-dried for $60 \mathrm{~min}$ in a safety cabinet at room temperature. The glass slides were fixed with chilled acetone for $10 \mathrm{~min}$. After fixation the slides were stored at $-80^{\circ} \mathrm{C}$ until use.

In the test, the slides were washed in deionized water for $3 \mathrm{~min}$, air-dried and covered with two-fold dilutions of test sera in PBS. After incubation for $1 \mathrm{hr}$ at room temperature or overnight at $4^{\circ} \mathrm{C}$, the slides were rinsed three times with PBS for 3 min each and thereafter the spots were filled with fluorescein conjugated anti-IgG (heavy \& light chains) rabbit serum (Cappel Laboratories Co., U.S. A.). The slides were washed again after incubation at $20-25^{\circ} \mathrm{C}$ in a moisture chamber for 45 min and mounted with $90 \%$ glycerine in carbonate buffer ( $\mathrm{pH} \mathrm{9.0)}$ and observed under fluorescent microscope (Olympus Optical Co., Tokyo).

Western blotting: The stocks of PVM and of $\mathrm{HVJ}$ were centrifuged at $5,000 \mathrm{rpm}$ for $10 \mathrm{~min}$ at $4^{\circ} \mathrm{C}$ and further ultracentrifuged at 100,000 $\mathrm{xg}$ for 2 hrs with a SRP28SA rotor (Hitachi Co., Tokyo). Pellets were suspended in $2 \mathrm{~m} \ell$ of PBS and layered on the top of a 15 to $60 \%$ sucrose linear gradient in $0.2 \mathrm{M}$ Tris- $\mathrm{Hcl}$ buffer $(\mathrm{pH}, 7.2)$ and ultracentrifuged for 16 hrs at $100,000 \mathrm{xg}$ using the same rotor. After centrifugetion, virus containing band was recovered, resuspended in Tris-buffer, and re -ultracentrifuged at $100,000 \mathrm{xg}$ for $2 \mathrm{hrs}$ to remove sucrose. The final samples were resuspended in a small amount of Tris- $\mathrm{HCl}$ buffer and used as antigen. The antigen was 
mixed with an equal volume of $2 \%$ sodium dodecyl sulfate-2\% 2-mercaptoethanol, boiled for $2 \mathrm{~min}$ at $100^{\circ} \mathrm{C}$ and was applied for electrophoresis with a $10 \%$ sodium dodecyl sulfate -polyacrylamide slab gel (SDS-PAGE) by the Laemmli method [12]. Viral proteins in SDS -PAGE were transferred to Durapore-membrane (Nippon Millipore Inc., Tokyo) . Appropriate dilutions of sera were applied to sheets which were blocked with a $10 \%$ solution of skim milk to avoid nonspecific reactions. After being washed, the membrane sheets were processed using a Vectastain $\mathrm{ABC}$ kit (Vector Lab. Ltd., U.S.A.) .

Statistical analysis: Serological results were statistically analyzed by Wilcoxon's signed ranks test [22], using IBM 9377 as the mainframe computer with SAS Statistical Software.

\section{Results}

Evaluation of serological methods for the detection of PVM antibody:Sixty sera with HI antibody titer ranging from high to low were used for this purpose. As shown in Fig. $1 \mathrm{a}$, discrepancy between RDE-treated and untreated sera was observed for the sera with antibody titers lower than $2^{5}$. Out of 21 untreated sera, 11 sera with titers of $2^{4}$ and $2^{5}$ were considered to be false positive since HA inhibiting activity was abolished by RDE treatment. Spearman's correlation coefficient $\left(r_{\mathrm{S}}\right)$ was estimated to be 0.72 and $\mathrm{Y}=0.25+1.02 \mathrm{X}$. The same rat sera were examined for IFA test. As shown in Fig. $1 \mathrm{~b}$, a higher antibody titer, generally two-fold higher, was obtained by IFA test than HI test with RDE treatment. The $r_{s}$ was 0.58 and $\mathrm{Y}=$ $2.62+0.40 \mathrm{X}$. Furthermore, reliability was also higher in IFA test. Although higher positive rate by $35 \%$ was obtained by $\mathrm{HI}$ test without RDE treatment than IFA test (Fig. 1 c), this increased rate was assured to be due to positive reactions caused by a nonspecific inhibitor(s) to PVM-HA.

Detection of PVM antibody in various laboratory animals: The prevalence of PVM antibody was investigated for rat, mouse, hamster and rabbit sera by IFA test obtained from research facilities and commercial breeding colonies in Japan during the period of 1984 to 1990. Results of the test on a total of 1,280 sera are shown in Table 1. The viral infection was
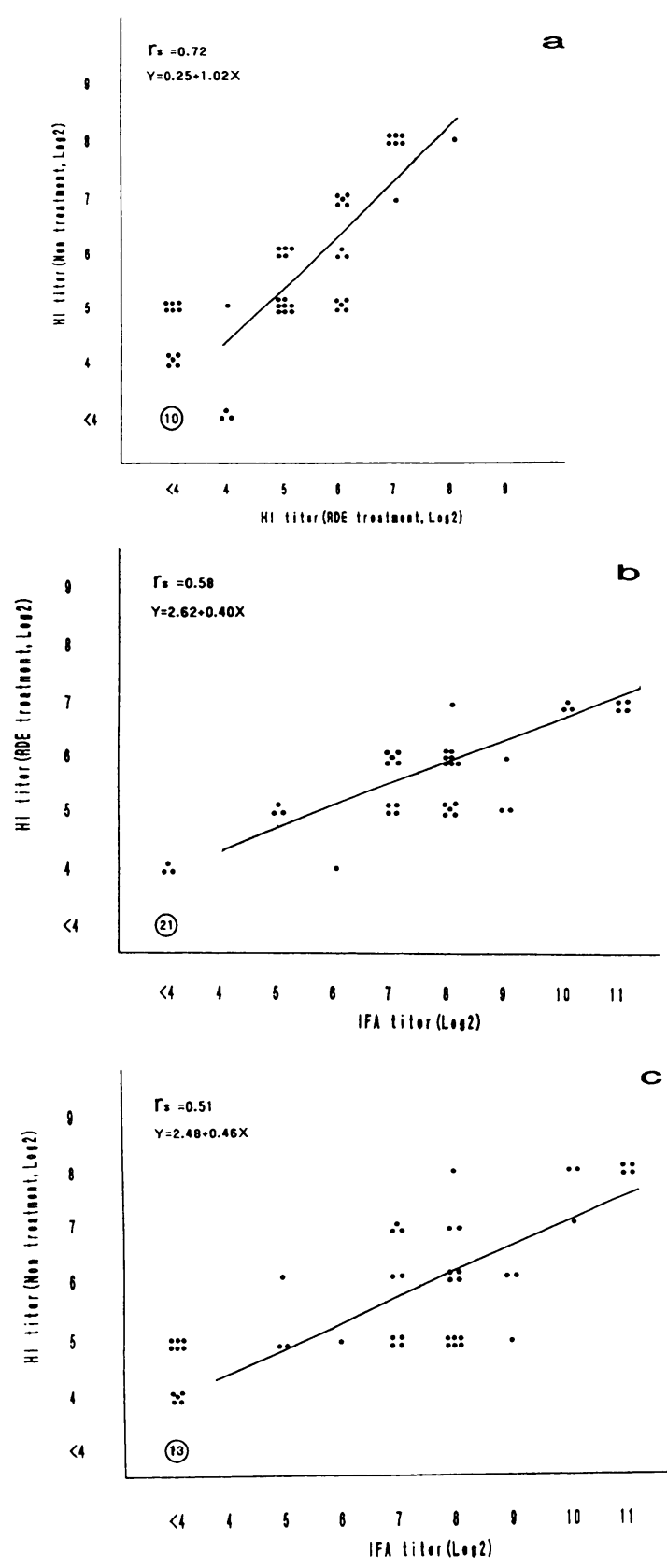

Fig. 1. Comparison of 3 serological tests (Parker's original $\mathrm{HI}$, modified $\mathrm{HI}$ by the use of RDE, and IFA)

more prevalent in rats in commercial breeding colonies compared with other laboratory animals, i.e. mice, hamsters and rabbits. A commercial rat colony (Code C) operated under conventional condition showed the highest incidence of antibody $(30 / 62,48.4 \%)$. Moreover, 
Table 1. Detection of PVM antibody in animal sera from commercial breeders and research facilities $(1984-1990)^{*}$

\begin{tabular}{cllc}
\hline Source of sera & $\begin{array}{l}\text { Animal } \\
\text { Species }\end{array}$ & $\begin{array}{l}\text { Condition of } \\
\text { maintenance }\end{array}$ & $\begin{array}{c}\text { Incidence of } \\
\text { antibody }{ }^{* *}\end{array}$ \\
\hline $\begin{array}{c}\text { Commercial } \\
\text { breeder }\end{array}$ & & & \\
A & Mouse & SPF & $0 / 31(0)$ \\
B & Mouse & Clean & $0 / 22(0)$ \\
C & Rat & Conventional & $30 / 62(48.4)$ \\
D & Rat & Conventional & $0 / 10(0)$ \\
E & Rat & SPF & $60 / 200(30.0)$ \\
F & Hamster & Clean & $0 / 56(0)$ \\
Research & & & \\
facility & & Conventional & $0 / 153(0)$ \\
G & Mouse & Conventional & $65 / 490(13.3)$ \\
H & Rat & Conventional & $21 / 112(18.8)$ \\
I & Rat & Conventional & $2 / 144(1.4)$ \\
J & Rabbit & &
\end{tabular}

* : A sample was evaluated as positive by IFA test when its fluorescence against the antigen slide was more than $1: 10$ of reciprocal highest dilution of serum. Numbers in parenthesis show the positive rates in percentage. ${ }^{* *}$ : No. in parenthesis indicate percentage.

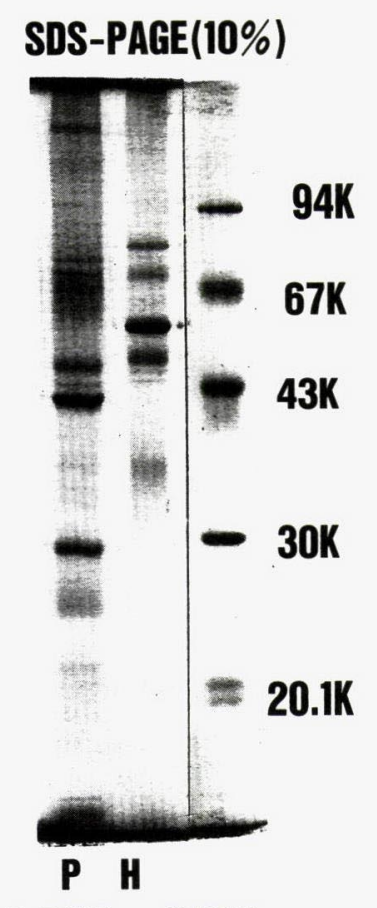

\section{P:PVM H:HVJ}

Fig. 2. SDS-PAGE analysis of viral protein of PVM and HVJ. The standard markers for molecular weight are shown on the right side.

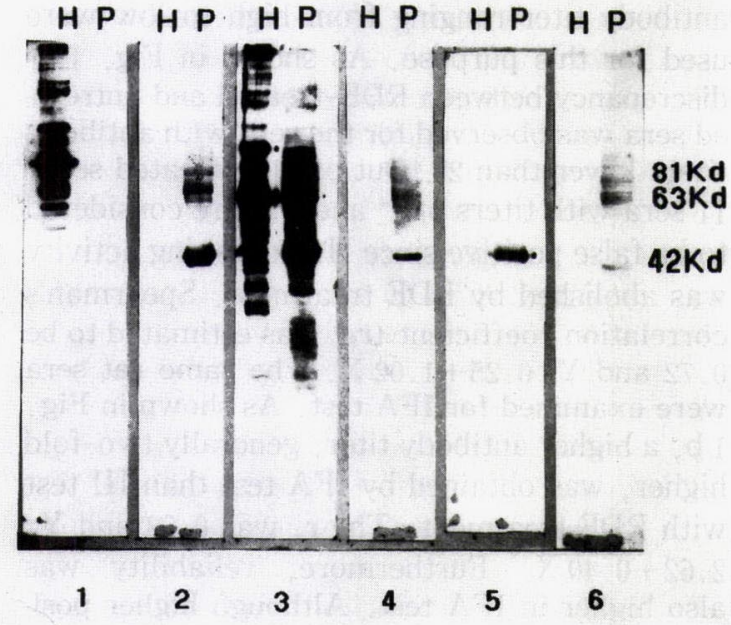

Fig. 3. Western blotting analysis. Antigen $\mathrm{H}: \mathrm{HVJ}$ viral proteins $P$ : PVM viral proteins Sera

1 : Experimentally infected rat serum with HVJ 2 : Experimentally infected rat serum with PVM 3 : Naturally infected rat serum (Table 1 , Code C) 4 : Naturally infected rat serum (Table 1 , Code $\mathrm{H}$ ) $5:$ SPF rat serum (Table 1 , Code E) 6: Rabbit serum (Table 1, Code J)

one commercial rat colony under SPF condition (Code E) was also positive $(60 / 200,30.0 \%)$. In research facilities, two rat colonies (Code 
H, I) examined were positive, $13.3 \%$ and 18 . $8 \%$, respectively. No evidence of infection was found in mice and hamsters in this survey.

Interestingly, 2 of 144 Japanese white rabbits $(1.4 \%)$ in a research facility (Code $\mathrm{J}$ ) were also positive. The IFA titers of these rabbits were 640 and 2,560, and those of HI titer were 640 and 1,280 , respectively. The antibody specificity of rabbit sera was confirmed by SDS -PAGE and Western blotting as shown in Figs. 2 and 3 ; rabbit sera reacted with three viral proteins of molecular weight $81 \mathrm{Kd}, 63 \mathrm{Kd}$ and $42 \mathrm{Kd}$ as like as the serum of an experimentally infected rat. These proteins were thought to be VPII, III and IV, as previously reported [4].

\section{Discussion}

PVM is one of the most prevalent respiratory viral pathogens affecting laboratory animals in the U.S.A. and Europe $[7,13]$, and measures should be taken to prevent rodents reared in research and breeding facilities from the infection. Nude mice have been shown to be highly susceptible to PVM exhibiting a severe form of the disease $[19,21]$. In Japan, evidence of PVM infection in mice and rodents was reported in 1986 by Parker's original HI test using a commercial antigen [9]. The present study disclosed that treatment with $\mathrm{RDE}$ is essential to remove non-specific HA inhibitor (s), revealing that the significance of the low antibody titer detected without RDE treatment in 1986 is obscure. IFA method has never been used for PVM antibody in Japan. IFA test was shown to have higher sensitivity than HI test and was assumed to be comparable to ELISA $[10,17]$. Specificity of the IFA test was also confirmed by the western immunoblotting analysis. These results indicate usefulness of IFA test for a small scale microbiological monitoring rather than the HI and ELISA tests.

Using IFA test, markedly high incidence of PVM antibody was demonstrated, indicating that PVM infection does exist in Japan. Tumor -bearing rats from a certain cancer research institute in Japan also showed a high PVM antibody titer by IFA test (data not shown) . Although the transmission of PVM in laboratory animals occurs mainly by aerosol, introduction of PVM into rat colonies by infected tumor cells may occur as like as the case of hemorrhagic fever with renal syndrome
(HFRS) virus in rats [23] and lymphocytic choriomeningitis virus (LCM) in mice [1]. PVM antibody-positive rats from conventional colonies have also been found to be infected with HVJ (shown in Fig. 3, lane 3) at a rate of nearly $50 \%$ (data not shown). In contrast, only $10 \%$ of $\mathrm{HVJ}$-infected rats were positive for PVM. This result indicates that HVJ is more contagious than PVM in rats. The demonstration of PVM antibody in 2 rabbits indicates that further examination on rabbits is needed to clarify the effect of PVM infection in rabbits. The monitoring of PVM infection in the colonies of commercial breeders and research facilities in Japan will be more important, since number of research using immunodeficient rodents which are highly susceptible to PVM is increasing.

This experiment was performed at Laboratory Animal Center for Biomedical Research, Nagasaki University School of Medicine. We are grateful for the contribution of BHK-21 cell from Japanese Cancer Research Resources Bank. This work was supported by Grant-in-Aid (No. 62780058 ) for Scientific Research from the Ministry of Education.

\section{References}

[1] Bhatt, P. N., Jacoby, R. O., and Barthold, S. W. (1986). Contamination of transplantable murine tumors with lymphocytic choriomeningitis virus. Lab. Anim. Sci., 36, 136

[2] Burnet, F. M. and Stone, J. D. (1947). The receptor -destroying enzyme of V. Cholerae. Austral. J . Exp. Biol., 25, 227-233.

[3] Casals, J. and Brown, L. V. (1954). Hemagglutination with arthropod-borne viruses. J. Exp. Med., 99, 429-449

[4] Cash, P., Preston, C. M., and Pringle C. R. (1979). Characterization of murine pneumonia virus proteins. Virology, 96, 422-452.

[5] Clarke, S. K. R. and Saynor, R. (1959). Hemagg lutination-inhibition tests against CA virus. Arch. Ges. Virusforsch., 9, 288-294.

[6] Disk, E. C. and Mogabgab, W. J. (1961). Characteristics of parainfluenza 1 (HA2) virus. II. Hemagg. lutination, hemagglutination-inhibition and neutralization. Am. J. Hyg., 73, 273-281.

[ 7 ] Gannon, J. and Carthew, P. (1980). Prevalence of indigenous viruses in laboratory animal colonies in the United Kingdom 1978-1979. Lab. Anim ., 14, 309-311.

[8] Iwai, H. (1978). Serological examination on natural infections with mouse pathogens in inbred mouse strains : Difference in antibody detection among the strains. Exp. Anim., 27, 17-20.

[9] Kagiyama, N., Takakura, A., and Itoh, T. (1986). A serological survey on 15 murine perhogens in mice and rats. Exp. Anim., 35, 531-536.

[10] Kraft, V. and Meyer, B. (1986). Diagnosis of murine infection in relation to test methods employed. Lab. 
Anim. Sci., 36, 271-276.

[11] Laufs, R. and Thomssen, R. (1968). Inhibition der Rubellavirus-Hemagglutination. I. Eigenschaften eines in fetalem Kalberserum vorkommenden Inhibitor der Rubellavirus-Hemagglutination in vitro. Arch. ges. Virusforsch., 24, 181-191.

[12] Laemmli, U, K. (1970). Cleavage of structural proteins during assembly of the head of bacteriophage T 4. Nature, 227, 680-685.

[13] Lussier, G. and Descoteaux, J. (1986). Prevalence of natural virus infections in laboratory mice and rats used in Canada. Lab. Anim. Sci., 36, 14-18.

[14] Miyata, H. and Sato, H. (1990). Theiler's murine encephalomyelitis virus-Characterization of newly isolated viruses from Japanese mouse colonies. Exp. Anim., 39, 539-548.

[15] Parker, J. C., O'Beirne, A. J., and Collins, M. J., $\mathrm{Jr}$. (1979) . Sensitivity of enzyme-linked immunosorbent assay, complement fixation, and hemagglutina. tion inhibition serological tests for detection of Sendai virus antibody in laboratory mouse. J. Clin. Mi. crobiol., 9, 444-447.

[16] Parker, J. C., Tennant, R.W., and Ward, T.G. (1966). In Viruses of Laboratory Rodents. pp. 22-45, Andervort, H.B. (ed.), National Cancer Institute, Bethesda.
[17] Payment, P. and Descoteaux, J-P. (1978). Enzyme -linked immunosorbent assay for the detection of antibodies to pneumonia virus of mice in rat sera. Lab. Anim. Sci., 28, 676-679.

[18] Porterfield, J. S. and Rowe, C. E. (1969). Hemagglutination with athropod-borne viruses and its inhibition by certain phospholipids. Virology, 11, 765-770.

[19] Richter, C. B., Thipen, J. E., Rishter, C. S., and Mackenzie, J. M., Jr. (1988). Fatal pneumonia with terminal emaciation in nude mice caused by pneumonia virus of mice. Lab. Anim. Sci., 38, 255-261.

[20] Sato, H. and H. Miyata. (1986). Detection of lymphocytic choriomeningits virus antibody in colonies of laboratory animals in Japan. Exp. Anim. 35, 189-192.

[21] Weir, E. C., Brownstein, D. G., Smith, A. L., and Johnson, E. A. (1988). Respiratory disease and wasting in athymic mice infected with pneumonia virus of mice. Lab. Anim. Sci., 38, 133-137.

[22] Wilcoxon, F. (1945). Individual comparisons by ranking methods. Biometrics, 16, 80-83.

[23] Yamanishi, K., Ribeilo, F., Dantas, M., Takaha. shi, M., Yamanouchi, T., Domae, K., Kawamata, J., and Kurata, T. (1983). Isolation of hemorrhagic fever with renal syndrome virus from tumor specimen of a rat. Biken J., 26, 155-160.

\title{
ラットにおけるマウス肺炎ウイルス (PVM)の血清学的証明
}

\author{
宮田博規・渡辺洋二・近藤久義* 一八神健一**・佐藤 浩 \\ 長崎大学医学部附属動物実験施設 \\ *長崎大学医学部附属原爆資料センタ一調査部 \\ **筑波大学医学系動物実験センター
}

マウス肺炎ウイルス（PVM）の感染把握を目的と

して, その特異抗体の定量を三種類の血清学的試験法 (二種の血球凝集抑制試験「 $\mathrm{H} \mathrm{I} 」$ 法並びに間接巣光 抗体法「IFA」) で吟味したところ，I F Aが最も感 度並びに特異性に関し優れていた。この結果, I F A 法は動物実験施設等を対象とする小規模的なモニ夕 リングの適用に実用性から選択肢の一つであること が確認された。この方法を使用して, 我が国の研究機 関およびブリータ一由来の実験動物 (ラット, マウス, 八ムスター, モルモット，ウサギ) の 1,280サンプル を对象として, PVMの感染流行の有無を血清学的方
法により検索した。その結果，実験動物の中で特にコ ンベンショナルラット $(116 / 674 ; 17.2 \%)$ と S P F ラット $(60 / 200 ; 30.0 \%)$ で高率に抗体が検出された。 また,コンベンショナルウサギにおいても低率なが ら，抗体陽性固体 $(2 / 144 ； 1.4 \%)$ を認めた。しかしな がら，ハムス夕ーやマウスでは抗体陽性固体を検出す ることが出来なかった。これらの結果から，我が国の コンベンショナルコロニーやS P Fコロニーにも，欧 米同様 P V M 感染が存在し, 今後 S P F ラット・マウ スの検查項目として全ブリーダーでとりあげる必要 性が示哮された。 